\title{
REPRESENTASI TUTURAN DIREKTIF DALAM TERJEMAHAN KITAB DHAMMAPADA BAB PAPA VAGGA
}

\author{
Danang Try Purnomo \\ STAB Negeri Raden Wijaya Wonogiri \\ danangtrypurnomo@gmail.com
}

\begin{abstract}
Abstrak
Tulisan ini mendeskripsikan penggunaan tindak tutur ilokusi direktif yang terkandung dalam kitab Dhammapada. Data tulisan ini diperoleh dari sumber kepustakaan, yakni kitab Dhammapada bagian Papa Vagga yang bertemakan 'kejahatan.' Dari hasil analisis data diperoleh bahwa tindak tutur direktif 'teguran' dan 'nasihat' adalah tindak tutur paling banyak digunakan dalam merealisasikan pesan kebenaran ajaran keagamaan. Sementara itu, jenis tindak tutur lain ditemukan adalah 'larangan,' 'ajakan,' dan 'permintaan.' Perbedaan kuantitas penggunaan tindak tutur tersebut merepresentasikan fenomena alami dari peristiwa tutur sesuai dengan tujuan dan konteks sosialnya, yakni menyampaikan ajaran sesuai dengan permasalahn yang dibicarakan.
\end{abstract}

Kata kunci: tindak tutur, direktif, syair Papa Vagga

\section{Abstract}

This paper describes the use of directive illocutionary speech acts contained in the Dhammapada. The data of this paper was obtained from literature sources, namely the Dhammapada section of Papa Vagga with the theme 'crime.' From the results of data analysis, it was found that the directive speech act 'reprimand' and 'advice' are the most used speech acts in realizing the message of the truth of religious teachings. Meanwhile, other types of speech acts found are 'prohibitions,' 'invitations,' 'and' requests. 'Differences in the quantity of speech acts represent the natural phenomena of the speech event according to the purpose and social context, which is to convey the doctrine according to the problem being discussed.

Keywords: speech acts, directive, Papa Vagga

\section{Pendahuluan}

$\begin{array}{rrr}\text { Teks } & \text { sebagai } & \text { bentuk } \\ \text { komunikasi } & \text { verbal } & \text { memiliki }\end{array}$

sejumlah kaidah lingual, seperti morfologi, sintaksis, semantik, dan pragmatik. Setiap kaidah lingual terdapat batasan-batasan tertentu yang membedakan satu sama lain. Perbedaan yang dimaksud merujuk pada cara peneliti dalam mengkaji 
suatu objek. Teks sebagai bentuk wacana tutur merupakan manifestasi pesan yang disampaikan penutur kepada mitra tuturnya. Bentuk tuturan verbal sangat beragam bergantung dari objek yang dituju dan tujuan sosialnya, seperti naskah pidato, surat teguran, teks kontrak, media sosial, dan lain sebagainya. Setiap jenis komunikasi verbal tersebut merepresentasikan gaya yang berbeda baik dari gaya yang disampaikan maupun daya tutur yang diharapkan. Gaya dapat dipahami sebagai cara yang khas dipergunakan oleh manusia untuk mengutarakan atau mngungkapkan diri secara personal. Cara pengungkapan tersebut bisa melalui aspek kebahasaan seperti diksi, bahasa kias, bahasa figuratif, struktur kalimat, berntuk-bentuk wacana dan sarana retorika yang lain (Satoto, 2012:35)

Berkaca dari hal tersebut, teks dalam kitab suci termasuk jenis dari komunikasi verbal yang khas dan tidak biasa. Dikatakn demikian karena kitab suci bersumber dari Sang Tuhan kemudian ditransmisikan melalui kognisi manusia melalui utusan-Nya dan diserap oleh umatnya. Proses komunikasi yang sinergis antara teks yang tertulis dalam kitab dan umat sebagai pembacanya memiliki daya tutur yang mampu menggerakkan manusia untuk berbuat sesuatu berdasarkan keyakinannya. Daya tutur dalam hubungan sosial merupakan unsur yang sangat penting dalam retorika komunikasi. Para penutur mengeksplorasi segenap kemampuan bahasannya untuk merealisasikan kehendak sesuai dengan tujuan sosialnya.

Dalam khazanah telaah pragmatik, daya tutur tergramatiasi dalam satuan tindak tutur yang bertahap. Tahapan-tahapan tindak tutur tersebut merupakan substansi dari mekanisme tuturan dalam kajian pragmatik. Lebih lenjut, Gunarwan (1994: 84) berpendapat bahwa pragmatik mengkaji mekanisme ujaran, bukan makna kalimat yang diujarkan itu. Selain itu, pragmatik juga mempelajari fungsi ujaran yaitu untuk apa suatu ujaran dibuat atau dilakukan. Satuan analisisnya bukanl kalimat (karena kalimat adalah satuan tata bahasa), melainkan tindak ujaran atau tindak tutur (speech act). Karena itu, satuan analisis pragmatik adalah tindak tutur. Tindak tutur atau tindak ujar (speech act) merupakan 
entitas yang bersifat sentral dalam pragmatik. Karena sifatnya yang sentral tersebut tindak tutur bersifat pokok di dalam pragmatik (Rustono, 1999:31).

Searle (dalam Suwito, 1983:33) berpendapat bahwa dalam setiap komunikasi bukanlah sekedar lambang, kata, atau kalimat, tetapi lebih tepat jika disebut produk atau hasil lambang, kata atau lebih tegasnya bahwa tindak tutur adalah produk atau hasil dari suatu kalimat dalam kondisi tertentu dan merupakan kesatuan terkecil dari komunikasi linguistik yang dapat berwujud pernyataan, pertanyaan, perintah, atau maksud yang lainnya. Secara spesifik maksud itu tergramatisasi dalam tindak tutur ilokusi. Tindak ilokusi mempermasalahkan maksud penutur dalam sebuah tuturan (Searle, 1978:42-50; (Gunarwan dalam Bambang Kaswanti Purwo 1994:8485; Clark, 1996:133). Untuk itu, tindak ilokusi dapat dirumuskan dengan pertanyaan untuk apa tuturan itu dilakukan?. Maksud dibedakan dengan makna. Maksud adalah unsur luar bahasa yang berada di pihak penutur, sedangkan makna adalah unsur dalam bahasa (Verhaar, 1981:129-131). Karena berada di luar bahasa, maksud hanya dapat diketahui jika mengaitkan tuturan dengan konteksnya.

Secara lebih terperinci, tindak tutur dibagi menjadi tiga yaitu tindak lokusi (locutionary act), tindak ilokusi (ilocutionary act), dan tindak perlokusi (perlocutionary act) (Austin 1968) (Searle, 1974). Tindak lokusi adalah tindak tutur untuk menyatakan sesuatu. Tindak tutur ini disebut sebagai The act of saying something. Kunjana Rahardi (2005:35) menyatakan bahwa tindak lokusioner adalah tindak tutur dengan kata, frasa, dan kalimat sesuai dengan makna yang dikandung oleh kata, frasa, dan kalimat itu. Sementara itu, Austin mengatakan bahwa tindak ilokusi adalah tindak melakukan sesuatu (dalam Rustono, 1999:35). Tindak ilokusi merupakan tindak tutur yang mengandung maksud dan fungsi atau daya tuturan. Tindak tutur ini sering disebut The act of doing something. Tindak Perlokusi

Tindak perlokusi adalah tindak tutur yang pengutaraannya dimaksudkan untuk mempengaruhi 
lawan tuturnya. Tindak tutur perlokusi disebut sebagai The act of affecting someone. Tuturan yang diucapkan seorang penutur sering memiliki efek atau daya pengaruh (perlocutinary force). Efek yang dihasilkan dengan mengujarkan sesuatu itulah oleh Austin dinamakan tindak perlokusi (dalam Rustono, 1999:36). Efek atau daya tuturan itu dapat ditimbulkan oleh penutur secara sengaja, dapat pula secara tidak sengaja. Tindak tutur yang pengujarannya dimaksudkan untuk mempengaruhi mitra tutur inilah merupakan tindak perlokusi.

Dari ketiga tahapan dalam tindak tutur di atas, tindak tutur ilokusi menjadi fokus dalam kajian ini. Tindak tutur ilokusi mempunyai beberapa fungsi tindak tutur di dalamnya. Searle (dalam Leech, 1993:164) menjelaskan fungsi-fungsi tindak tutur sebagai berikut. Pertama adalah tindak tutur Representatif atau Asertif (Asertives). Pada ilokusi ini seorang penutur terikat pada kebenaran proposisi yang diungkapkan, misalnya menyatakan, mengusulkan, membual, mengemukakan pendapat, dan melaporkan. Dilihat dari segi sopan santun ilokusi-ilokusi ini cenderung netral, yaitu termasuk katagori bekerjasama (collaborative). Kedua, tindak tutur direktif dipahami sebagai ilokusi yang bertujuan menghasilkan efek berupa tindakan yang dilakukan oleh penutur ilokusi ini, misalnya; memesan, memerintah, memohon, menuntut, dan memberi nasihat. Jenis ilokusi ini dapat dimasukkan ke dalam katagori-katagori yang membutuhkan sopan santun negatif. Namun, di pihak lain terdapat juga beberapa ilokusi direktif, seperti mengundang yang secara intrinsik memang sopan. Ketiga, tindak tutur komisif (Commissives dapat didefinisikan sebagai ilokusi yang terikat pada suatu tindakan di masa depan, misalnya menjanjikan, menawarkan, mengancam, menolak, dan sebagainya. Jenis ilokusi ini cenderung berfungsi menyenangkan dan kurang bersifat kompetitif karena tidak mengacu pada kepentingan penutur tapi pada kepentingan petutur. Keempat, tindak tutur ekspresif merupakan ilkosi yang mengungkapkan atau mengutarakan sikap psikologis penutur terhadap keadaan yang tersirat dalam ilokusi. Misalnya mengucapkan terima kasih, 
mengucapkan selamat, memberi maaf, mengecam, memuji, mengkritik, mengeluh, mengucapkan bela sungkawa, dan sebagainya. Kelima, tindak tutur deklarasi (Declarations) adalah jenis ilokusi yang pelaksanaannya akan mengakibatkan adanya kesesuaian antara isi proposisi dengan realitas, misalnya mengundurkan diri, memecat, memberi nama, menjatuhkan hukuman, mengucilkan, mengangkat (pegawai) dan sebagainya.

Dari kelima macam tindak tutur tersebut peneliti akan memfokuskan kajian dalam kitab Dhammapada pada tindak tutur direktif. Pertimbangan yang diambil adalah bahwa tindak tutur direktif merepresentasikan suatu aksi terhadap reaksi yang disampaiakn penuturnya. Dalam hal ini adalah teks Dhammapada sebagai bentuk ujaran yang disampaikan oleh Sang Buddha secara alamiah menyiratkan suatu daya perintah kepada umat untuk melaksanakan sesuatu. Secara lebih khusus syair Dhammapada yang digunakan dalam kajian ini adalah bagian Papa Vagga, yakni syair yang membicarakan ihwal kejahatan yang dilakukan oleh manusia. Oleh katrena itu, pola komunikasi yang terbentuk secara lazim dan alamiah akan mendekripsikan larangan dan peringatan agar menjahui perbuatan jahat. Verba-verba direkstif yang terbentuk dalam terjemahan syair dhammapada itu akan diklasifikasikan sesuai dengan jenis dan fungsi tindak tutur direktif yang tertulis di dalam kitab tersebut.

\section{Metodologi}

Jenis penelitian adalah kualitatif, yakni menyatakan prosedur penelitian yang menghasilkan data deskriptif berupa kata-kata tertulis atau lisan dari orang-orang dan perilaku yang dapat diamati (Bogdan dan Taylor dalam Moleong, 2005: 4). Sementara itu, Mahsun (2005: 233) menyebut kualitatif karena penelitian ini bertujuan untuk memahami fenomena-fenomena kebahasaan yang terjadi dan tidak terkait dengan perhitungan angka sebagai hasil akhir. Data bukanlah sebagai objek penelitian melainkan bahan jadi penelitian. Data adalah semua informasi atau bahan yang 
disediakan alam (dalam arti luas) yang harus dicari dan disediakan dengan sengaja oleh peneliti yang sesuai dengan masalah yang diteliti (Sudaryanto, 2015: 4). Data tulisan ini adalah teks terjemahan syair Dhammapada bab Papa Vagga Sementara itu, objek kajian ini adalah bentuk-bentuk tuturan ilokusi direktif yang terkandung di dalam teks tersebut. Adapun teknik pengumpulan data dalam penelitian ini adalah teknik pustaka, yakni teknik pemerolehan data bersumber pada bahan tertulis yang dibatasi oleh maksud dan tujuan penelitian (Subroto, 2007: 48)

\section{Hasil Pembahasan}

Peran tindak tutur direktif
adalah memberikan pesan kepada
lawan tutur untuk melakukan suatu
tindakan. Peran tersebut
mengimplikasikan bahwa memiliki
daya yang lebih besar untuk
memengaruhi mitra buicaranya.
Mitra bicara yang dimaksudkan
adalah umat Buddha yang
mempelajari Dhamma. Realisasi
tindak tutur direktif yang muncul
dalam syair Dhammapada Papa

Vagga adalah perintah, permintaan, ajakan, nasihat, kritikan, teguran, ancaman dan larangan

\section{Perintah}

Bentuk verba dari perintah adalah memerintah yang dalam Kamus Besar Bahasa Indonesia dapat diartikan memberi perintah, atau menyuruh melakukan sesuatu (tim penyusun KBBI V: 2016). Tindak tutur direktif yang menunjukkan bentuk perintahtampat pada kutipan berikut.

\section{(1) Bergegaslah berbuat kebajikan, dan kendalikan pikiranmu dari kejahatan;}

Tuturan direktif yang ditunjukkan pada kutipan (1) di atas adalah ketika penutur langsung secara tegas memberikan perintah kepada umat untuk berbuat kebajiukan dan mengendalikan diri dari pikiran dan nafsu jahat.

2. Ajakan

Bentuk verba dari ajakan adalah mengajak. Dalam Kamus Besar Bahasa Indonesia mengajak 
diartikan menyilakan, menyuruh supaya turut; atau membangkitkan hati supaya melakukan sesuatu (tim penyusun KBBI V: 2016). Bentuk tuturan direktif yang semakna dangan maksud terebut adalah sebagai berikut.

(2) Apabila seseorang berbuat jahat, hendaklah ia tidak mengulangi perbuatannya itu

(3) Apabila seseorang berbuat bajik, hendaklah dia mengulangi perbuatannya itu dan bersuka cita dengan perbuatannya itu,

(4) demikian pula orang yang mencintai hidup, hendaknya

menghindari racun dan hal-hal yang jahat

$\begin{array}{clc} & \text { Realisasi tuturan direktif } \\ \text { yang mengandung unsur ajakan }\end{array}$ tampak pada tuturan (2), (3), dan (4) di atas ditandai dengan penanda lingual hendaklah, dan hendaknya. Sang Buddha mengajak manusia untuk senantiasa berbuat kebajikan dan menjahui segala tindakan kejahatan, termasuk ajakan bagi orang yang mencintai hidup agar senantiasa menghindari hal-hal tidak terpuji.

3. Nasihat

Dalam Kamus Besar bahsa Indonesia menasihati diartikan memberikan ajaran atau pelajaran yang baik (tim penyususn KBBI V: 2016). Makna ajaran terebut dapat berfungsi Ddalam konteks anjuran, petunju $\mathrm{k}$, dan teguran. Wujud tindak tutur direktif yang menyiratkan nasihat dapat ditunjukkan dalam contoh berikut.

(5) sungguh membahagiakan akibat dari memupuk perbuatan bajik

(6) Pembuat kebajikan hanya melihat hal yang buruk,selama buah perbuatan bajiknya belum masak,tetapi bilamana hasil perbuatannya itu telah masak,ia akan melihat akibat-akibatnya yang baik 
(7) demikian pula orang bijaksana sedikit demi sedikit memenuhi dirinya dengan kebajikan

(8) Bagaikan seorang saudagar yang dengan sedikit pengawal membawa banyak harta, menghindari jalan yang berbahaya,

(9) Apabila seseorang tidak mempunyai luka di tangan,

maka ia dapat menggenggam racun.

Racun tidak akan mencelakakan orang yang tidak luka.Tiada penderitaan bagi orang yang tidak berbuat jahat

Tuturan direktif (5) - (10) di atas menunjukkan bentuk komunikais yang mengandung unsur nasihat. Pada tuturan (5) bentuk nasihat direalisasikan dengan memberi pengetahuan bahwa berbuat baik akan membawa kebahagiaan. Tuturan direktif (6) ditunjukkan dengan sikap kerendahan hati bahwa orang baik akan selalu merasa bahwa apa yang dilakukan masih jauh dari kata baik mekipun sebenarnya baik. Pada tuturan (7) merupakan bentuk anjuran bahwa orang bijak mengisi kebaikan sedikit demi sedikit. Sementara itu pada tuturan (8) tuturan direktif nasihat merujuk pada peringatan untuk menghindari jalan yang berbahaya. Tuturan mengisyaratkan suatu informatif bahwa orang yang berbuat baik pasti hati selalu merasa bahagia. Hal terebut diibartkan dengan luka dan racun, yakni orang baik tidak memiliki luka sehingga ketika memegang racun atau sesuatu yang buruk, maka tidak akan tersakiti

4. Teguran

Dalam kamus Besar bahasa Indonesai menegur diartikan memperingatkan atau mengkritik terhadap sesuatu yang tidak baik (tim penyusun KBBI V: 2016). Perbuatan menegur ini pada umumnya merupakan wujud dari dampak adanya ketidakbaikan yang dilakukan manusia. Oleh karen itu teguran diperlukan untuk dapat kembali mengajak kepada jalan yang lebihh baik. Bentuk tuturan direktif 


\author{
teguran yang tampak dalam data \\ adalah sebagai berikut
}

(10) Barang siapa lamban berbuat bajik, maka pikirannya akan senang dalam kejahatan.

(11) Pembuat kejahatan hanya melihat hal yang baik,selama buah perbuatan jahatnya belum masak, tetapi bilamana hasil perbuatannya itu telah masak, ia akan melihat akibatakibatnya yang buruk

(12) Bagaikan sebuah tempayan akan terisi penuh oleh air yang jatuh setetes demi setetes, demikian pula orang bodoh sedikit demi sedikit memenuhi dirinya dengan kejahatan.

(13) Barangsiapa berbuat jahat terhadap orang baik, orang suci, dan orang yang tidak bersalah, maka kejahatan akan berbalik menimpa orang bodoh itu,bagaikan debu yang dilempar melawan angin

(14) Sebagian orang terlahir melalui kandungan; pelaku kejahatan terlahir di alam neraka; orang yang berkelakuan baik pergi ke surga; dan orang yang bebas dari kekotoran batin mencapai nibbana.

(15) Tidak di langit, di tengah lautan, di celah-celah gunung atau di manapun juga, dapat ditemukan suatu tempat bagi seseorang untuk dapat menyembunyikan diri dari akibat perbuatan jahatnya.

(16) Tidak di langit, di tengah lautan, di celah-celah gunung atau di manapun juga, dapat ditemukan suatu 
tempat bagi seseorang untuk dapat menyembunyikan diri dari kematian

Terdapat tujuh bentuk tuturan direktif yang mereflekikan teguran. Teguran yang muncul dalam tuturan di atas pada umumnya menunjukkan suatu ancaman kepada manusia yang menebarkan kejahatan. Sebagaimana tampak pada tuturan (10) yakni orang yang lamban dalam berbuat baik akan tergeru dalam kejahatan. Tuturan (11) memperlihatkan kesombingan orang yang selalu merasa berbuat baik psdahal yang esungguhnyya masih jauh dari kata baik. Pada tuturan (12) digunakan bentuk pengandaian air dan tempayan, yakni orang jahat sedikit demi sedikit akan menumpuk terus menerus kejahatannya. Sementara itu tuturan direktif (13) adalah teguran yang berupa ancaman, yakni orang bodoh yang berbuat kejahatan di masa yang akan datang akan mendapatkan balsan yang sesuai dengan perbuatannya.demkian pada tuturan (14) merupakan bentuk peringatan ekaligus ancaman yang berlawanan, yakni orang baik akan mendapatkan balasan surga, edangkan orang jahat akan terlahir atau mendapatkan neraka. Tuturan (15) dan (16) adalah bentuk ancaman yang keras disampaiakn kepada umat berbuat kejahatan, yakni di mana pun keberadaannya perbuatan buruknya tidak dapat ditutupi meskipun disembunyikan dan tidak akan dapat menghindar pula dari kematian mekipun sudah bersembunyi di tempat yang dirasa paling aman.

5. Larangan

Istilah melarang dalam Kamus Besar bahasa Indoneia diartikan memerintahkan upaya tidak melakukan sesuatu atau tidak memperbolehkan berbuat sesuatu (tim penyusun KBBI V: 2016). Tuturan direktif yang merefleksikan bentuk larangan dapat ditunjukkan pada kutipan berikut.

(17) dan jangan merasa senang dengan perbuatan itu, sungguh menyakitkan akibat dari memupuk perbuatan jahat 
(18) Jangan meremehkan kejahatan walaupun kecil, dengan berkata: "Perbuatan jahat tidak akan membawa akibat".

(19) Janganlah

meremehkan

kebajikan walaupun kecil dengan berkata:"Perbuatan bajik tidak akan membawa

akibat."Bagaikan sebuah tempayan akan terisi penuh oleh air yang dijatuhkan setetes demi setetes,

Penanda lingual yang mencirikan bentuk larangan pada kutipan (17), (18), dan (19) di atas diwujudkan dengan kata jangan. Kata jangan menunjukkan larangan yang tegas diberikan oleh penutur terhadap mitranya. Bentuk larangan pada tuturan (17)adalah larangan bagai orang yang befrbuat jahat agar tidak merasa senang. Lebih lanjut terdapat ancaman bahawa orang yang berbuat jahat itu dapat memperoleh balasan yang lebih menyakitkan. Sementara itu, pada tuturan (18) manusia dilarang utnuk mengabaikan perbuatan jahat meskipun hanya berifat kecil. Akhirnya pada tuturan (19) berisi larangan pula agar manuia tidak meremehkan kebaikan meskipun hanya kecil.

Variasi bentuk tuturan direktif yang ditunjukkan dalam kutipan Dhammapada bagian Papa Vagga di atas merupakan proses alamiah peristiwa tutur. Dalam proses menghendaki sesuatu yang diharapkan melalui tahapan-tahapan cara tujuan tutur. Perintah, ajkan, teguran, nasihat, dan larangan sebagaimana yang ditemukan dalam data tersebut merupakan variasi tindak tutur direktif yang masingmasing tuturan memiliki penanda lingual berbeda. Apabila dideskripsikan, proses cara-tujuan tuturan dalam syair Dhammapada Papa Vagga di atas dapat ditunjukkan dalam bagan berikut.

Proses Cara-Tujuan Tuturan 


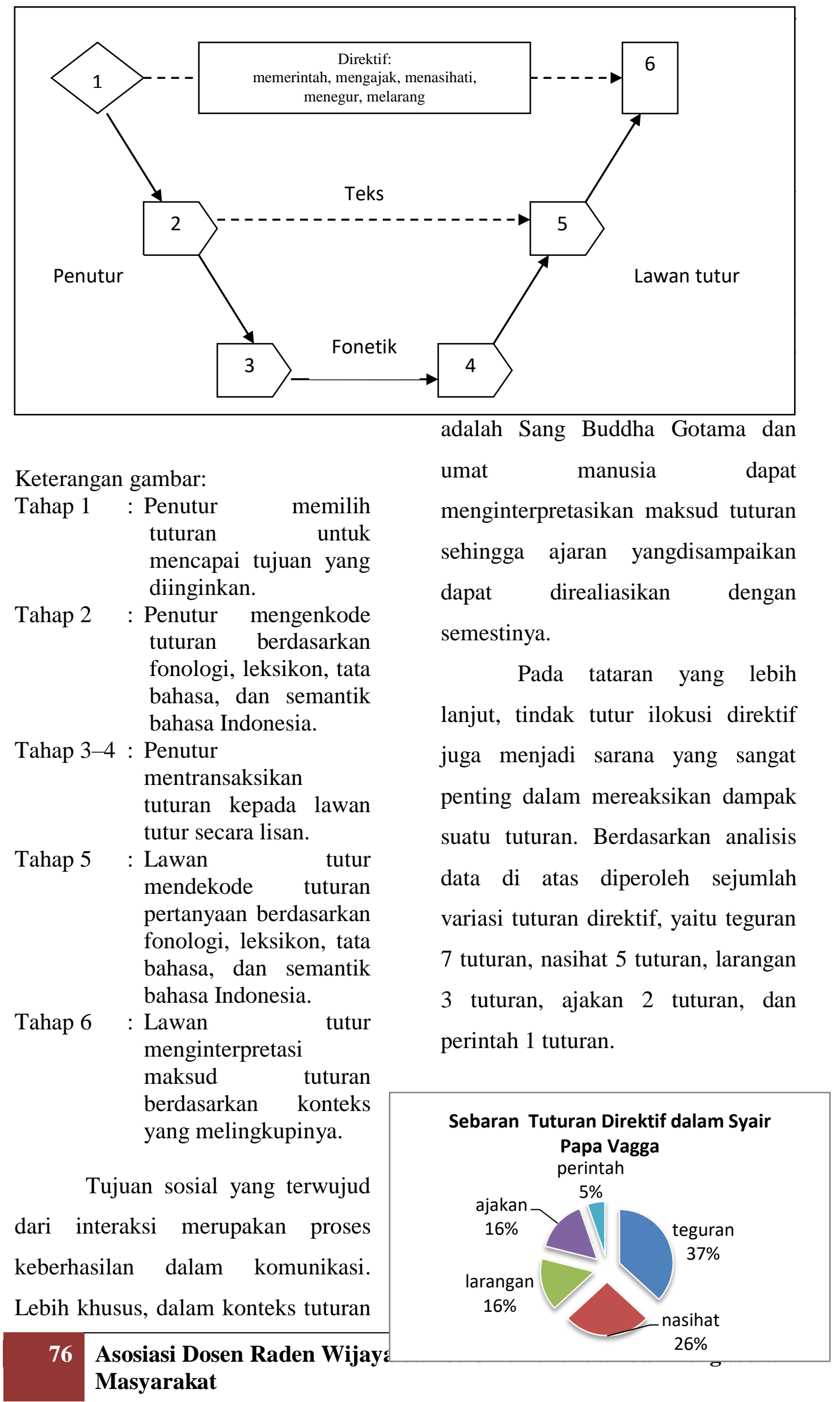


Sebaran data di atas menggambarkan pola kecenderungan jenis tutura $\mathrm{n}$ direktif, yakni teguran paling banyak ditemukan sebesar $39 \%$, nasihat $28 \%$, larangan dan ajakan $16 \%$ dan perintah $5 \%$. Sebaran penggunaan tindak tutur tersebut mengimplikasikan tujuan sosial. Syair Dhammapada bagian Papa Vagga secara garis besar berbicara tentang kejahatan yang dilakukan oleh manusia. Implikasi dari tema besar terebut, syair ini didomiinasi oleh tuturan direktif teguran. Teguran yang dimaksudkan adalah bentuk peringatan lugas yang disampaikan Sang Buddha agar manusia terhindar dari perbuatan jahat. Sebagaimana dicontohkan tututran (10) dan (11) di atas, manusia diperingatkan agar terhindar dari pikiran jahat. Sementara itu, pada tuturan 13 sampai dengan (16), bentuk tuturan direktif teguran mengandung unsur ancamanancaman, yakni manuia mendapatkan balasan yang setimpal atau karma di masa mendatang bila melakukan kejahatan.

Selain berupa teguran, tuturan direktif yang muncul adalah memberikan nasihat. Nasihat yang tampak adalah bahwa orang baik akan mendapatkan kebahagiaan sebagaimana tuturan (5), (6), dan (7). Sementara itu, tuturan (8), dan (9) merealisasikan bahwa orang baik akan terhindar dari keburukan manakala yang bersangkutan selalu dalam keadaan waspada dan berhatihati, bahkan 'racunpun' diibaratkan tidak dapat melukai orang yang baik tersebut; tuturan (9).

Bentuk tuturan direktif larangan terdapat dalam sairterjemahan Dhammapada Papa Vagga diatndai dengan kata “jangan.” Kata "jangan” dalam teks tersebut merujuk kepada pemahaman bahwa manusia dilarang meremehkan perbuatan buruk meskipun kecil. Sebaliknya, manusia dilarang pula agar tidak meremehkan perbuatan baik meskipun nilaianya juga kecil sebagaimana kedua hal tersebut digambarkan pada tuturan (17), (18), dan (19).

Tuturan direktif berupa ajakan mengimplikasikan keinginan penutur agar manusia tidak mengulangi perbuatan buruk dan menghindari segala keburukan itu; tuturan (2), (3), dan (4). Lebih lanjut jenis tuturan direktif memerintah (1) 
menindikasikanperintah langsung kepada manusia agar berbuat baik, baik perilakui maupun mentalnya. Berdearkan sajian analisis data tersebut leel tuturan yang muncul dari yang terbanyak dan paling sedikit adalah teguran, nasihat, larangan/dajakan, dan perintah. Proe komunikasi alamiah yang muncul dari peristiwa bahasa dalam syair tersebut mendeskripsikan bahwa berbicara perihal kejahatan dibutuhkan daya ilokusi direktif yang fundamental untuk menimbulkan efek kepada lawan tuturnya yang dalam hal ini adalah umat Buddha yang membaca Dhammapada. Oleh karena itu, jenis teguran (yang di dalamnya terdapat ancaman) merupakan benuk retorika kebahaaan yang diperlukan untuk menhindarkan orang dari perbuatan jahat, sedangkan nasihat berperan dalam mengarahkan manusia meninggalkan perbuatan buruk

\section{Kesimpulan}

Pesan tutur melalui teks kegamaan memiliki daya implikasi sesuai dengan tujuan sosialnya, yakni menyampaikan ajaran kebenaran. Pola hubungan partiipan yang terpentuk dalam teks adalah tidak sejajar atau hubungan vertikal, yakni Sang Buddha terhadap umatnya. Pada teks terjemahan Dhammapada bagian Papa Vagga yang bertema 'kejahatan' terkandung keterpolaan penggunaan ujaran berdasarkan daya tutur ilokusi direktif. Tindak tutur direktif 'menegur' paling banyak ditemukan karena berdasarkan titik ilokusinya tindak tutur ini merepresentasikan kebenaran proposisi yang sudah menjadi kelaziman dalam memperingatkan manusia agar tidak salah jalan dalam melaksanakan kehidupan sesuai dengan perintah Sang Pencipta. Selanjutnya, tindak tutur direktif 'menasihati' merepresentasikan keingingan agar bijak dalam memutuskan dan malakukan segala hal, sedangkan tindak tutur direktif 'larangan' dan 'ajakan' mengimplikasikan bahwa manusia agar lebih berhati-hati dalam mengontrol hawa nafsunya agar tidak terjerumu dalam kenistaan. Sementara itu, tindak tutur direktif 'perintah' dalam bab Papa Vagga ini tidak banyak ditemukan. Hal tersebut merepresentasikan proses terbentuknya wacana teks yang sudah terpola secara alamiah, yakni 
baba yang berbicara tentang

'kejahatan' didominasi oleh teguranteguran yang bermuatan peringatan sekaligus ancaman.

\section{Daftar Pustaka}

Austin, J.L. (1968). How to Do Things with Words. New York: Oxford University Press.

Gunarwan, Asim. (1994). "Kesantunan Negatif di Kalangan Dwibahasawan Indonesia-Jawa di Jakarta:: Kajian Sosiopragmatik," dalam PELLBA 7. Jakarta: Unika Atma Jaya.

Leech, Geoffrey. (2015). PrinsipPrinsip Pragmatik. (ediai terjemahan M.D.D Oka) Jakarta: Universitas Indonesia Press.

Levinson, Stephen C. (1983). Pragmatics. Cambridge: Cambridge University Press.

Lexy Moleong. (2001). Metodologi Penelitian Kualitatif. Bandung: Rosidakarya.

Mahsun M.S, (2005). Penelitian Bahasa: Tahapan, Strategi, Metode dan Tekniknya. Jakarta: Grafindo Persada.
Satoto, Soediro. (2012). Stilistika. Yogyakarta: Ombak

Searle, John R. (1974). Speech Acts: An Essay in the Philosophy of Language. Cambridge: Cambridge University Press.

Subroto, Edi. (2007). Pengantar Metode Penelitian Linguistik Struktural. Surakarta: Universitas Sebelas Maret Press.

Sudaryanto. (2015). Metode dan Aneka Analisis Data. Yogyakarta: Duta Wacana University Press..

Suwito. (1983). Pengantar Awal Sosiolinguistik. Surakarta: Henary Offset Solo.

Tim penyusun. (2016). Kamus Besar Bahasa Indoneia edisi $V$ (versi daring). Jakarta: Kemdikbud

Verhaar, J.W.M. (1981). Pengantar Lingguistik (Jilid 1). Yogyakarta: Gadjah Mada University Press.

Sumber internet

https://samaggiphala.or.id/tipitaka/papa$\underline{\text { vagga/ }}$ 